\title{
STUDYING QUILOMBOLA PRACTICES OF RESISTANCE ON INSTAGRAM
}

\section{ESTUDANDO PRÁTICAS QUILOMBOLASDE RESISTÊNCIA NO INSTAGRAM}

\author{
Djankaw Matheus Marques* \\ Mabia Camargo ${ }^{* * * * *}$
}

\section{RESUMO}

Este artigo analisa a forma como processos de subjetivação são performados na mídia social Instagram por Djankaw, uma quilombola negra e trans. A partir de uma perspectiva foucaultiana de análise do discurso, pela qual o poder é compreendido como ação e, que, o seu exercício envolve resistências, os múltiplos recursos semióticos mobilizados por Djankaw em seu Instagram indicam como os processos de subjetivação são interseccionados à raça, classe, etnia, sexualidade e religião, configurando práticas de resistência contra narrativas hegemônicas coloniais. As performances de Djankaw na internet instigam um debate produtivo sobre a identidade Afro-brasileira 'quilombola' e ressoam com as lutas dos grupos marginalizados pela ocupação de diversos tempo-espaços no interior do Brasil. As postagens de Djankaw e suas práticas corpóreas operam como sítios propícios ao questionamento sobre o que significa ser negra, trans e quilombola. A complexidade das posições de sujeito de Djankaw é aumentada por sua conexão com diferentes religiões; ela incorpora diferentes práticas espirituais que também orquestram discussões sobre raça, sexualidade e gênero. Quando Djankaw performa suas subjetividades na internet, ela mobiliza e reconfigura essas marcas sociais ao mesmo tempo em que se engaja em práticas semióticas de resistência contra o apagamento histórico das culturas quilombolas no Brasil e a emancipação dos discursos sobre o colonialismo.

Palavras-chave: mídias sociais; processos de subjetivação; interseccionalidade; resistência.

\section{ABSTRACT}

This article analyzes how processes of subjectivation are performed on the popular image-based social media Instagram by Djankaw, a black trans resident of a quilombo [a settlement founded by descendants of formerly enslaved African-Brazilians]. Following a Foucauldian analysis of discourse whereby power is seen to be exercised wherever there is resistance, we look at how Djankaw's processes of subjectivation intersect with race,

\footnotetext{
* UUndergraduate Student in Social Work, Universidade Centro de Ensino Superior de Maringá, UNICESUMAR, Polo EaD Guarapuava, Paraná, Brasil. Activist and Coordinator of Coletivo Bajubá.djankawtrans@gmail.com.

Orcid: https://orcid.org/0000-0003-2539-6120

** Universidade Estadual do Centro Oeste, UNICENTRO, Guarapuava, PR, Brasil.

*** Universidade Federal do Rio de Janeiro, UFRJ, Rio de Janeiro, RJ, Brasil. camargomabia@gmail. com Orcid: https://orcid.org/0000-0003-0080-5645
} 
class, sexuality, and religion, becoming practices of resistance against hegemonic colonial narratives. Djankaw's performances on the Internet instigate a productive debate over the African-Brazilian quilombola identity itself and resonate with the struggles of marginalized groups to reclaim their diverse time-spaces in the interior of Brazil. Djankaw's posts and their embodied practices operate as sites to question the meanings of what it means to be black, trans, and quilombola [an inhabitant of a quilombo]. Further, the complexity of Djankaw's subject positions is increased by their connection to different religions: they incorporate different spiritual practices that also orchestrate discussions on race, sexuality, and gender. While performing their selves on the internet, Djankaw mobilizes and re-shapes bodily social marks, at the same time that they participate in semiotic practices of resistance against the historical erasure of quilombola cultures in Brazil and claim their emancipation from colonialism.

Keywords: social media; processes of subjectivation; intersectionality; resistance.

\section{INTRODUCTION}

Social networks have been integrated into our daily life to make the way we interact with others easier and fast. Although the virtual interaction between users of social media seems simple, it is a very complex process that affects both how we look at others and understand them, and how we look at ourselves and present ourselves to the world. Social media allows its users to rely on different semiotic resources to conceive different ideas of who they are and expand the image of themselves. Digital technology has a key role in creating multiple timespace potentials for interaction and socialization through the act of sharing written text, photographs, videos, emojis, and gifs (POULSEN et al., 2018). The semiotic practices created on these networking sites can be powerful resources for exploring their multimodal meanings and for doing and undoing subjectivities.

Instagram, the popular online photo-sharing social media application (app), is used worldwide and has increased in popularity not only as a 'diary' for its users, but also as a network hub, allowing users to share content by posting videos and photographs while interacting with others. Instagram posts produce visual and textual impressions in a multisemiotic range that relies on the scrutiny of an audience (RASSI, 2016). As a complex and fluid space that foregrounds its users' interactions, Instagram can be analyzed as a potential time-space for performing multisemiotic practices that potentialize and constrain subjectivities: it can be used to challenge and shatter power relations in oppressive regimes of normativity as well as to determine and establish the limits to these very practices. Following Foucault's maxim that power and resistance go hand in hand, we aim to discuss to what extent this digital technology can be seen as a space that allows self-empowerment and resistance to semiotic regimes such as colonialism, transphobia, and racism. 
Djankaw, a Black, trans, quilombola artist, undergraduate student, activist and eco-friendly constructor, engages in processes of subjectivation on Instagram that are intersected with race, class, sexuality, and religion. Djankaw's posts show how their ${ }^{1}$ body operates as a site of fluid meanings, which is also seen here as a site of resistance to the historical erasure of quilombola cultures in Brazil and experiences of precariousness (BUTLER, 2018). History has shown us that minority groups have been marginalized and put out of the reach of public policies due to the fact that their practices, race, and religions, among other characteristics, have constantly been considered to be barbarian or alien. They have thus been forced to live with less access to public policies and economic resources, and with less power in society in comparison to dominant groups. Thinking about social media and the use of networks in our everyday social practices, groups such as LGBTIQA+ have struggled to access digital technologies, which have been shared unequally along online time-spaces.

Despite the vast array of accounts that reproduce normative and privileged portrayals of people on Instagram - usually white and/or rich people, who show the 'best' of their expensive lifestyle -, few profiles manage to be examples of diversity and subversion of the mainstream online personas. Djankaw is an example of a producer of "differentiation" on the internet. On Djankaw's posts, they assert that they belong to different minority groups as they play with the profusion of differences that shape their nonconforming social existence. There are multiple ways they use the app to challenge normative discourses, particularly the posting of photographs and videos of their everyday routine that is not glamorized. Djankaw's daily posting practices consist of showing them singing, dancing, playing musical instruments, reciting poetry, working in the bakery house of the quilombo, planting vegetables, etc. On their Instagram profile, Djankaw describes themself as a dancer, performer, singer, hair braid stylist, farmer, baker, and undergraduate student. As an activist that actively participates in a wide range of different social spaces, they enact forms of resistance and political visibility online and offline.

Another aspect of resistance on their Instagram profile is the way Djankaw manages specific vocabulary using slang, jargon, storytelling, dialects, and songs, constantly confounding static definitions of gender and sexuality, as they refer

\footnotetext{
1. The reader ought to pay attention that, due to Djankaw's gender fluidity, references are made by means of the personal pronouns 'they' and 'them', the possessive adjective 'their' and the reflexive pronoun 'themself'. This is complicated by the fact that this paper is authored in full partnership with Djankaw, blurring the lines between researcher and subject creating a plural Djankaw per se in the writing process, and when the personal 'we' is used, reference is attributed to both research participants, Mabia and Djankaw.
} 
to themselves in their profile with both pronouns throughout. For instance, defining themselves as Djankaw Matheus, they explain that the word "Djankaw" means "the mystic who dances", which comes from their experiences as a dance performer and their encounters with West-African Yoruba culture and language. The name "Djankaw" implies no gender or sex determination, while "Matheus" (i.e. Matthew) is their birth name chosen by their family under the influence of the Christian tradition. According to Christian mythology, Matthew was one of the twelve apostles of Jesus, and in the case of this study or as common sense, it can be addressed as a male name. The deconstruction of Djankaw's male name provides a larger view of the intersections they mobilize in the production of transgressive movements on Instagram.

When Djankaw engages in networked practices on social media to (re)define their own body and, by extension, their territory, they enlarge the definitions of their subjectivities while also reaffirming local kinship ties. We understand such multisemiotic practices as performances that invite the audience's gaze to move in Djankaw's direction, that is, processes of creating subjectivities and meanings through language use. It is a two-fold and concurrent movement: the analysis of Djankaw's performances on two of their Instagram posts indicates how they are mobilizing the app both to be seen as belonging to specific spaces - the quilombo where they live, and the LGBTIQA+ group of which they are part and to subvert these very fixed notions by intersecting different semiotic regimes that help to create subjectivities and practices of resistance.

The following section presents the historical, political, and legal trajectory of the quilombo in which Djankaw lives. The third section explores the notion of multisemiotic practices from the perspective of performativity, which is then deployed in the fourth section to analyze how Djankaw uses Instagram to (re) signify the quilombo and intersect multisemiotic dimensions to question hegemonic views about subjectivities. We then conclude the article discussing the transience of subjectivities and how Djankaw emerges as a remarkable figure who develops open, vibrant, and transgressive practices of resistance in contemporary society.

\section{TRAJECTORIES OF RESISTANCE: QUILOMBO INVERNADA PAIOL DE TELHA}

Brazil's history as a nation-state is closely linked with the origin, development, and ongoing existence of quilombos. Slavery was the driving force behind the growth of the country's economy from the 1500s to the late 1880s. Black people were coercively brought to the Americas, deprived of their rights and free will, and 
exploited as manual labor force to the point of death. Unlike European immigrants, who proudly proclaimed attachment to their countries of birth while seeking a more prosperous future in their new home, Central and Eastern African tribes were decimated as African peoples were forcibly transported across the Atlantic and put to work in the colonies of Portugal and Spain, which are now independent nationstates in Central and South America (REIS; MAMIGONIAN, 2004). From the mid1500 s to 1850 , the transatlantic slave trade populated the Americas with around 3.5 million enslaved Africans, who were treated as merchandise and kept in deeply inhuman conditions. These enslaved people worked in agricultural production (sugar, cotton, tobacco), cargo transportation, urban services (carpentry, painting, bricklaying, shoemaking, blacksmithing), and domestic activities (GOMES, 2015).

The enslaved African populations who were forced to leave their home and brought to South America to work for the white European colonizers of this continent, have a significant role in the formation of the region that today is Brazil. Contemporary Brazil, although multicultural, has more than half of its population composed of enslaved African descendants. The fact that they were taken to become slaves, when the diasporic enslaved African people arrived in South America they had their oppression maximized in other levels; the enslaved African people in South America experienced all kinds of injustices caused mainly by racism and divisions of class and labor produced and perpetuated by different instances of power relations in colonial Brazil. The enslaved black bodies from Brazil's past suffered discriminatory treatment, inequalities in unfair policies, and lack of opportunities to have adequate life conditions: they had to live just to work, they were imprisoned, exposed to perpetual violence and forced to face the precariousness of colonization.

In spite of all this, slavery in colonial Brazil, as every system of oppression that cannot only be formed by its perfect and complete diffusion of power over all bodies and its own segments, gradually came to an end mainly through the rebellious enslaved Africans who fought for their lives by escaping their captivity. As Foucault claims, "where there is power, there is resistance" (1978, p. 95) and, when the enslaved African people ran away from their master's houses and started organizing themselves into communities, they were able to fight against their colonial oppressors and develop spaces of sociability; they resisted the violent system of slavery and also created something new - their own communities where they could experience a sense of freedom. These places were first seen as "runaway slave communities" - the quilombos - a concept created by the crown of Portugal, which reinforced the whitening project of the country's population and neglected 
the existence of African inhabitants in that period. Slavery was abolished in Brazil in 1888 and, since then, the meaning of quilombo has expanded beyond its original designation as a hideaway for slaves. Today, the term refers to "the formation of affinity groups that, looking for an autonomous and free production, came up against the slave system" (CARVALHO; LIMA, 2013, p. 331). Brazilian sociologist Clovis Moura is seen as the most relevant person for developing the notion of quilombo as a site of resistance (CRUZ et al., 2006).

Quilombos became legally safeguarded territories in the Brazilian Constitution of 1988. Article 68 of the Constitution recognizes the land occupied by the remaining quilombo inhabitants as their definitive property, assigning the State responsibility to grant them title to such lands (BRAZIL, 1988). The National Institute of Colonization and Agrarian Reform (INCRA) is the institution responsible for this legal process. It issued Decree No. 4887, of November 20, 2003 to regulate the identification, recognition, delimitation, demarcation, and titling of lands referred to in article 68 of the Brazilian Constitution. This decree states that quilombo communities should be recognized and demarcated based on the self-identification of the ethnic-racial groups that persisted in a given territory (BRAZIL, 2003). In order to become legally recognized as a quilombo, the living persons of a specific geographical space have to prove blood ties to Black ancestry related to the former slave resistance movements. The "quilombola identity" is thus produced through juridical and hereditary presumptions.

The history of the quilombola community analyzed in this article dates back to the mid-1860s, when Balbina Francisca de Siqueira-a wealthy woman and landowner of Capão Grande (a wintering farmland), in the city of Guarapuava, Paraná, in the interior of Brazil bequeathed a portion of her land to eleven formerly enslaved African-Brazilians that worked on her homestead raising livestock and performing domestic labor. She had emancipated them while she was alive, and the social organization of families in the mid-nineteenth century meant that "masters" and "slaves" lived together in alleged harmony through patronage relations (HARTUNG, 2004). The fact that Siqueira had no children may have influenced her decision to leave the land to her former slaves - a request that was specified in her will, and which was legally transferred to the group after Siqueira's suicide. Siqueira's siblings, who also received part of the land after her death, did not agree with the sharing of the property and refused to acknowledge and respect Siqueira's wishes. They intimidated the eleven families by attacking their homes, stealing their produce, and threatening them with death. Such violence and intimidation became 
ongoing practices in the lives of the African-Brazilian community that rightfully owned the land they inhabited.

Almost a century later, in early 1940, Southern Brazil became home for the European refugees of World War II, known as Danube Swabians (the ethnic Germanic population who lived in various countries of Southeastern Europe). These people arrived in the city of Guarapuava and built five traditional settlements (Vitória, Cachoeira, Jordãozinho, Samambaia, and Socorro) in a district called Entre Rios. These enclaves maintained the traditional ideologies and practices of their home countries, especially of German and Hungarian immigrants, who used the Swabian dialect as their mother tongue, designed their buildings according to the principles of Swabian architecture, and organized their political institutions in the manner of Swabian politics. In the 1970s, the group, commonly identified as German Brazilians, purchased the quilombo territory without accurate documentation. At the time, the land was in the possession of the Siqueira family after they had manipulated the quilombola group into signing expropriation documents. Having illegally bought these lands, the Swabians started an agricultural cooperation initiative, which today produces a variety of crops - transgenic wheat, corn, soy, and barley. The Swabians' agricultural business also significantly contributes to the brewing industry and the income of the state of Paraná. The Swabians eventually became a wealthy and politically powerful group interfering in the public policies of the region, where the quilombo is located.

With the establishment and influence of the Danube Swabians in the region, the descendants of the formerly enslaved African-Brazilians were gradually dispossessed of their inherited territory and permanently expelled by a Balbina Siqueira's nephew in 1975. The descendants of formerly enslaved African-Brazilians had to migrate and resettle at the periphery of the region. But the expropriation of such lands did not happen without resistance; a number of families refused to leave their homes and stayed in their lands, constantly facing attacks and acts of sabotage by the city's police officers and their accomplices, who supported the influential and well-off Swabians. This narrative demonstrates that even though the Swabians had inherited the territory and wanted to remain in a place with which they shared hereditary connections, the African-Brazilian communities had to face a long process of struggle. The African-Brazilian community's right to inhabit this land was-from the very beginning-achieved with fight and resistance, which continues to this day.

In 1998, in an attempt to deescalate the ongoing confrontation, INCRA (National Institute of Colonization and Agrarian Reform) gave the quilombola group 
a provisional territory to "face the situation and accommodate almost four hundred families that had set camp for eighteen months at the margins of the wintering lands" (HARTUNG, 2013, p. 329). Some elderly community members refused this other land primarily because it was not their legitimate, inherited territory, but also because it did not have a favorable topography for livestock. This dissent resulted in four separate groups of families being formed, which were located in four different regions: one in Guarapuava, one in Pinhão, one in Reserva do Iguaçú or Fundão (considered the "original" territory), and another one in the Danube Swabian enclave named Socorro, in the District of Entre Rios. The quilombo located in the Socorro enclave is considered by INCRA as a territory of "landless people" and not a quilombo area. In legal terms, this means that the land is registered as an "assentamento" (settlement community), a term used in Brazil to grant poor agricultural workers access to land.

On April 30, 2019, the quilombo community located in Reserva do Iguaçú was officially recognized as the first quilombola territory in the State of Paraná. The title was issued by INCRA after judicial determination, giving 225 hectares (from the total of 2,959) to the families of the people that inherited the lands. This means that the groups from the other three communities could go back to the "original lands" and live there legally. However, Djankaw decided not to move: they chose to stay on the "provisional lands" given by INCRA in 1998 where they and their family have lived and built their home and territory. By remaining on this provisional territory, Djankaw makes a statement that - regardless of geographical location and legal determination - they will continue to resist - with their body, spaces, and performances - the oppressions they and their group suffer every day.

The settlement community where Djankaw and their family live is "Invernada Paiol de Telha - Núcleo Assentamento" (Paiol de Telha Wintering Lands Settlement Community). There, Djankaw built their own house, made with the green building techniques that their ancestors used. As an artist, Djankaw performs, composes, sings, and dances authorial creations and often presents them in events and festivals that are held in the city. Djankaw also designs and fabricates jewelry and accessories using the natural resources of the land. The community produces its own organic crops and also sells different types of homemade bread to local schools. The community takes a strong stand against deforestation and its political agenda includes the preservation of the water springs found in the locality and resistance to the encroaching agricultural business.

The quilombola inhabitants of this community have made a temporary land into their permanent residence, developing alternative forms of governance, 
environmental sustainability, cultural heritage, and non-hierarchical relationships between quilombolas and non-quilombola peoples. They are an example of resistance and survival in contemporary times, especially because their trajectory has been marked by a history of land expropriation and bloodshed - a process of social regulation of the enslaved bodies. The colonial process produced many forms of oppression including racism, sexism, classism, transphobia, etc. (GOMES, 2019). In terms of emancipation, the quilombola group enacts a proactive reinforcement of practices, acknowledgement, experiences, opportunities, etc. that are produced collectively, and states the quilombo as a site of resistance, a point of confluence that intersects economic, cultural, political, territorial processes.

\section{DIGITALTECHNOLOGIESANDSUBJECTIVITIES:AGLANCEATPERFORMATIVITY}

The everyday digital use of texts, images, voices, and other semiotic practices reaches such a complexity that enables us to approach social networks as sites of intensive meaning production, with texts traveling across different time and space dimensions, thus producing multiple relations. In other words, observing the ways we interact online can help think about the intricacies of social practices that are constantly being negotiated in interactions, engendering diverse meanings. Such multiplicity of linguistic and nonlinguistic signs in interactional events is called multisemiotics, a concept that contributes to sociocultural understandings of everyday life practices on social network sites (FABRÍCIO, 2015; 2020).

Multisemiotic practices act in the construction and negotiation of subjectivities in dynamic and reflexive dimensions. This understanding has the potential to question the traditional conception of stability and fixity of the self to a wider range of meanings - subjectivities are mutable and constructed discursively, and analyzing this process requires attention to the effects of an ongoing process of repetition and difference that both sediments and naturalizes, and shakes meanings in different time and space dimensions. This perspective is necessary to the task of understanding how we use language to enact or construct subjectivities (BONFANTE, 2016).

Following this perspective, it is possible to observe the complex relationship between texts, body, and language use through multisemiotic practices. In the case of this study, multisemiotic practices are used as data to analyze how social meanings can operate political acts of (re)creating, (re)producing, and constraining particular social performances. Such semiotic practices allow minority groups that are outside of the reach of the State to interrogate, negotiate, reaffirm, and resist oppressive 
regimes that produce social inequalities. When referring to marginalized groups, for instance, sexual minorities face the risk of discrimination, vulnerability, and violence. Therefore, we argue that social inequality is being questioned on network sites through multisemiotic practices that operate by challenging normative discourses in what Rassi (2016, p. 65) called "instances of resistance".

These instances of resistance are understood here as "high performances" (COUPLAND, 2007, p. 146) which manage to catch the audience's gaze and hypnotize, as it were, the attendees. Djankaw's remarkability somehow works as a beacon from which the audience finds it hard to look away from. Whenever there is an audience to Djankaw's digital performances, the multiple meanings that give life to their performances are highlighted, enhancing the potential reflexivity of Djankaw's acts of nonconformity. Considering a few posts by Djankaw on Instagram, it can be seen that their semiotic productions as linguistic and bodily performances help to create the potentials and limits of their body, producing effects of time and space affectivities.

Concerning the multisemiotic practices that are being performed on the Internet, posts can be analyzed as powerful resources for creating realities. A post shared online operates not only in the sense of portraying the(one) self, but also producing ideologies, subjectivations, meanings, and relations. Further, semiotic practices can also question oppressive dominant regimes such as transphobia, racism, and colonialism. Although such regimes might be seen as relatively stable, in order to question them, we approach language as performative, an enactment that creates and shapes social realities through discursive practices (PENNYCOOK, 2007).

Language is performative to the extent that it is always citing and altering previous utterances. When Djankaw's body is shown to be a 'stage' in this article, it cites old meanings and produces new ones. This mechanism of repetition and difference happens because the audiences are active participants in the construction of meanings with the performer and because the audiences are always changing, a process that is exacerbated in online interactions. Djankaw's bodily practices and virtual posts mobilize the repetition of acts that produce effects and meanings that will be part of an on-going-making process of comprehending subjectivities as naturalized, normal or the ones that are marginal and regressive that challenge the standardized normative ones.

By analyzing how processes of subjectivation and intersections are being performed through multisemiotic practices on Instagram, the images posted online, captions for photographs and hashtags, among other activities such as reposts and pages/profiles followed, an understanding emerges about how the participation of 
individuals in social networks is intertwined with power dimensions. Power, according to Foucault (1978), is exercised onto populations, producing dichotomies such as modern vs. medieval, sanitary vs. dirty, healthy vs. ill, common vs. exceptional. These distinctions are then kept going by an intense process of vigilance over the conduct of individuals. These populational divides are then used to produce a body of knowledge (at hospitals, schools, churches, and other social institutions) on how individuals act and what can be done to make these bodies obedient. These very individuals who are deemed to be non-disciplined, upon being called a name, gain the right to speak about that which they are not. Subjectivation, thus, refers to a double process of 'being subjected to' and 'becoming a subject'. This is how power, knowledge and subjectivity intersect.

Intersectionality is a powerful analytical tool which can be used to study how categories of identity performativities of gender, race, religion etc. intersect in the production of social, political, and economic inequality (Crenshaw, 1994). The prism of intersectionality on which this work is grounded operates as a multidimensional construct that affects subjectivities by producing specific conditions of life for a particular individual in society. This concept operates by pointing to how tensions and provocations of regulation-emancipation (resistance) are complexified in the processes of enacting such performativities while exacerbating multiple ways of experiencing - and struggling through - power relations, especially the questioning of colonial narratives that uprise from Djankaw's posts.

Instagram, as a network platform, is also involved in this process, for it similarly participates in the formation of spaces that are constantly (re)created. It is important to state that this set of relations is viewed horizontally in this article and is considered irreducible to one single relation or another, forming a whole collective of bodies - a multiplicity - that produces difference. As an affective apparatus, digital technology provides a framework in which relations compose and decompose intensities that affect individuals (DELEUZE, 2002). The focus on affect promotes a view on sexuality, identities, and meanings as relational concepts in which affective intensities between bodies, subjectivities, and texts come to the foreground as a way of analyzing such recombination of language use and semiotic technology on contemporary digital time-spaces.

\section{STUDYING MULTISEMIOTIC PRACTICES OF RESISTANCE ON INSTAGRAM}

Instagram is used by Djankaw as a platform that produces instances of resistance in processes of subjectivation as for the quilombo where they live. The app 
gives more visibility to the quilombo territory and highlights the constant struggles the quilombolas have to engage in so as to remain on the land. Djankaw's posts generally depict the many practices and activities that take place in the quilombo: eco-friendly construction, bread making, hair braiding, ecology, craftwork, rituals, songs, and dances, among other manifestations of their intersections between African-American cosmologies.

The username chosen by Djankaw on the app is@djankawzando, a combination of the name they chose for themself and the Portuguese verb causar (i.e. to cause - a slang that means to impress or to shock in the Brazilian context) in its gerund form - causando. The use of " $z$ " instead of " $s$ " on the word comes from bajubá, a language created by the Brazilian trans community so that they could communicate secretly (CAMARGO, 2019). Djankaw's username on Instagram thus points to two different movements on the social platform: they are "causing a scene", meaning that they are provoking and shocking the audience (in the sense of the term in bajubá) and also "causing an effect", which refers to the act of producing the quilombo as a site of resistance on the Web.

In this analysis of Djankaw's profile, Instagram is seen as an affective agent, for it is part of the multiplicity of actors (and actions) that partake in the creation of the quilombo as a demarcated political space. The technological resources offered by the app are mobilized by Djankaw in order to broadcast the quilombo to a larger audience and also to show how that particular place is being inhabited - the peoples and practices that constitute the quilombo and the quilombola individuals. We selected two posts from Djankaw's Instagram that best illustrate the participation of the sociotechnical apparatuses of the platform in the process of constituting affective intensities such as subjectivities, bodies, places, and texts. We now turn our attention to the description of these posts. 


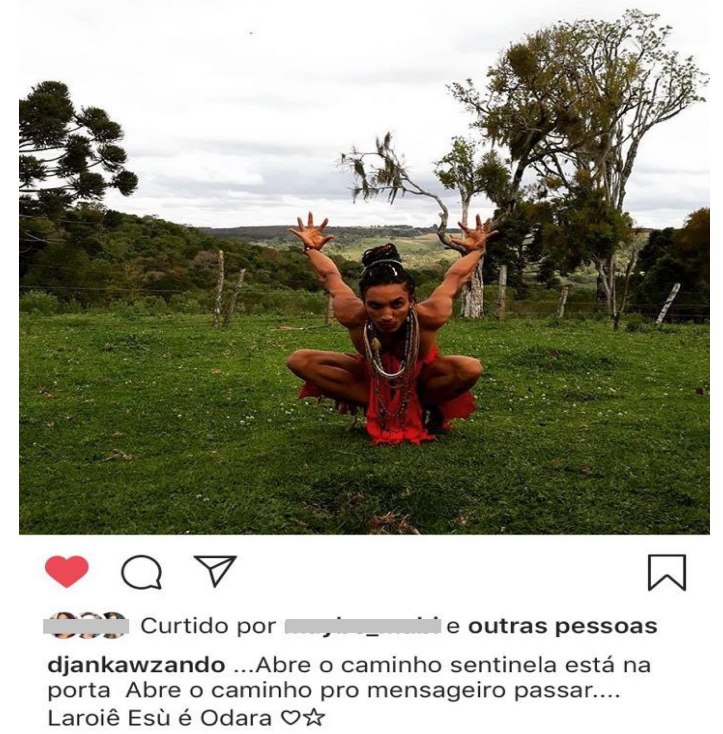

Figure 1. Djankaw performing a dance ritual

Figure 1 above depicts Djankaw performing a dance ritual at the "Comunidade Quilombola Paiol de Telha". The place where the performance takes place is the main area of the quilombo, where people gather for meetings, events, and for AfricanBrazilian religion practices, such as Candomblé and Umbanda. In the post under scrutiny, Djankaw appears dressed in red clothing that covers only the intimate parts of their body; they are also wearing accessories made of beads and their hair is braided. The image shows a performance where they are enacting a pose which includes the squatting of the feet forward and in which their body is almost fully displayed, exhibiting the contour of their muscles. The face is serious and the hands are directed to the background. It is possible to see their chest and that they do not have breasts.

The picture shows a landscape background in which the native forest helps produce the quilombo as a territory that reinforces a relatively stable relationship between the quilombolas and nature. However, such stability and harmony can be contested by the large fence that surrounds the landscape, separating it into two different spaces - one side is a stage for the performance itself and the other is where the forest is located. Further, the fence operates as a fortress that helps to 
establish what needs to be granted for the quilombo, protecting the territory and the native forest in relation to the constant risk of deforestation and exploitive interests that affect the quilombolas' lives. The fence not only splits the quilombo into parts, but it works constraining multiple meanings of everyday forms of resistance, such as the need to guarantee that the forest remains untouched by neocapitalist thinking that, with its ultimate force, aims to exploit it to make it a resource for commercial purposes.

This articulation of protecting the territory can be reaffirmed in one of their posts with the caption "...Abre o caminho / sentinela está na porta / Abre o caminho pro mensageiro passar.... / Laroiê Esù é Odara $\mathcal{O} \hat{z s}^{\prime \prime}$ [...Make way / The sentinel is at the door/Make way for the messenger to pass.... / Greetings to Exu, Exu is Gorgeous $\left.\mathcal{O}_{\hat{\imath}}\right]$. Laroiê is used to greet Exu and the word Odara means gorgeous; they are both Yoruba words. Esí (i.e. Exu) is the Orisha of communication in the Yoruba religion. As an Orisha, Esú connects with other entities, Orishas and the world. Esú is known as the intercessor deity that connects the spiritual and the physical world through communication. Esú opens the paths of spiritual awakening and must be the first Orisha to be saluted in this connection. We then understand that the performance enacts an invocation of Esú to spread "the message" that everything is connected - peoples, deities, nature, and technology. The intersections here point to the interplay of colonial narratives, religion, race and gender, exacerbating that different religious traditions - especially the African American ones - hold different empowering aspects for Djankaw.

By bringing religion to the centre of the debate, perhaps Djankaw is also attempting to intersect their birth Christian name Matheus to this invocation, considering that both Esú and the apostle are conceived as messengers of the spiritual world. Esú stands for breaking down the dualisms of their existence, reflecting the multiplicity of subjectivities that are articulated in their performances. The ancestor deity is not an essentialist self, it is used in a disruptive way that rejects a Christian affiliation and subverts it through Djankaw's polycentric religious practices and transgender body.

We argue that on this post the artistic performance is intertwined with a set of meanings and intensities, helping to create the quilombo as a territory that intersects Djankaw's transgender black body with African-Brazilian religious practices and with the quilombola ethnicity, affecting - composing and decomposing - what means to be a subject and how they resist through nonconforming meanings of multiple unexpected possibilities. In Djankaw's dance, nature and all the ritualistic practices are comprised in that territory and they become a subject on the app. The forest 
thus becomes a magical place where a multiplicity of agents, actions, and events can cohabit - a collective and many-fold choreography.

The second post selected for this analysis is displayed below and constitutes yet another example of the merging religious practices that are intertwined in Djankaw's semiotic practices on Instagram.

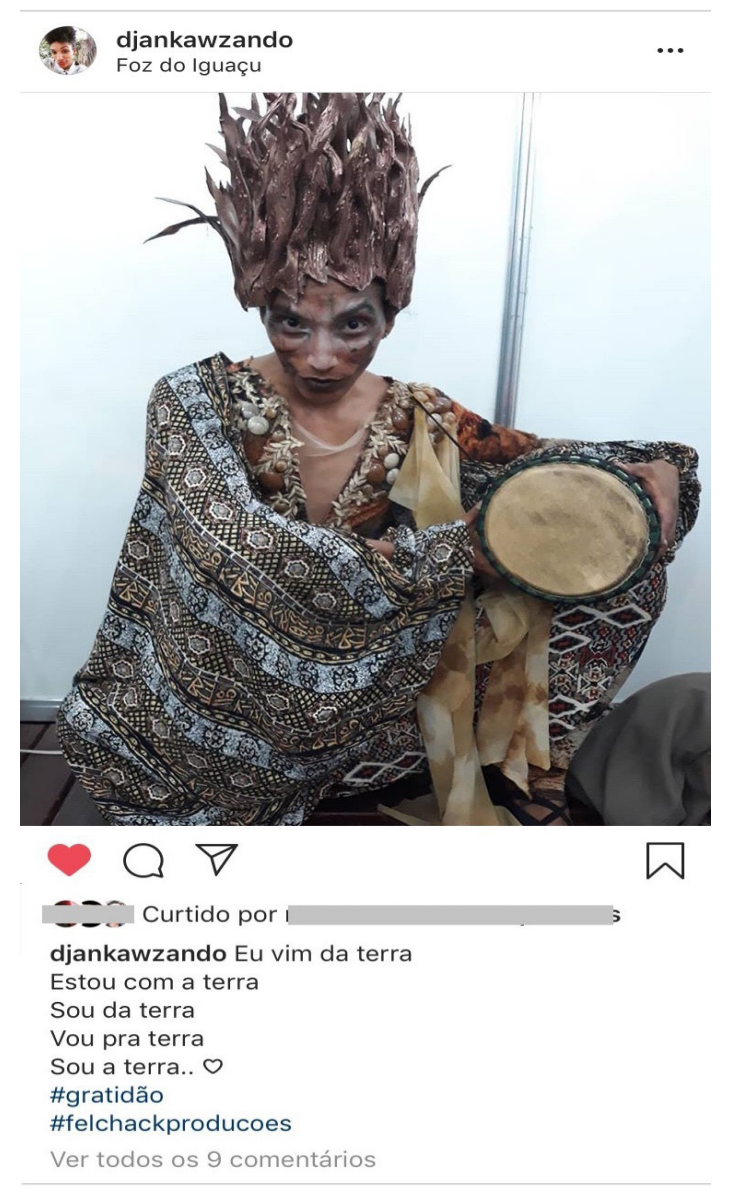

Figure 2. Djankaw in a highly stylized performance of religious hybridity

In the picture, Djankaw is depicted in a "high performance" (COUPLAND, 2007 , p. 146) where they are enacting a mystical character. It is possible to see how this production was carefully made through a vast set of semiotic resources such as makeup, hairstyle, clothing with African print, and other semiosis. These characteristics work in an affective movement, mixing aspects of art, religious, and 
everyday life practices with the effect that Djankaw creates their social reality where different categories can be critically and strategically conceived.

Make-up and costume were made in a combination of colors that highlights an aesthetic of 'natural' features, asserting the relation between nature and body, a relation that is intensified by the djembe (drum) under Djankaw's arms in the photograph. In Yoruba culture, the djembe plays an important role in producing sacred contexts; it is an integral part of summoning the spiritual deities to the physical world in rituals that usually involve songs and dance. The djembe is the communicator that connects heaven (orun) and earth (àiyê). We argue that the djembe is a musical instrument that operates as a form of black culture manifestation. Although these traits may be related to ancestral history, being emphasized in a specific culture Yoruba -, such artistic aesthetics is not isolated from contemporary issues. As this aesthetic performance is enacted in different time-spaces, it then follows that it can relocate and recreate unexpected meanings in different contexts.

The intersections with African-Brazilian religions can be observed through the Orisha called Onilé (Mother Earth) that is being performed by Djankaw; a performance that is also composed by the caption written under the picture: "Eu vim da terra / Estou com a terra / Sou da terra / Vou pra terra / Sou a terra.. O' $^{\prime}$ [I came from the earth / I am with the earth / I belong to the earth / I shall return to the earth / I am earth.. $]^{\prime}$ ". Onile is the Orisha of the biosphere; it is the energy of "Mother Earth" that balances all the elements in nature: earth, water, fire, air, including peoples and spirits. The multisemiotic resources mobilized on the app bring us to think about how Djankaw produces meanings about nature conceived as a place of habitation. Further, they indicate how planet earth through Onilé becomes home, as their own body is being mobilized to produce meanings of belonging, in the sense that body is home, earth and nature.

While hegemonic colonial narratives defined the planet as an unlimited resource able to be exploited, deforested and polluted, Djankaw-as-earth highlights moments of disrupting such discourses, as their body operates as a space for intersecting sustainable agricultural and eco-friendly practices through AfricanBrazilian cosmologies. Such productions assemble the fluidity of subjectivities, cultures, hierarchies, spaces, and religions in a relation that produces an understanding of the planet as a living being. The color brown used in Djankaw's make-up and costume ratifies their disruptive relation to hegemonic white narratives; the color also approaches African-Black narratives that assert that race is being experienced differently among racialized groups because of the color of their skin. Semiotic 
resources such as color, costume, etc. point to the intersections of race, class and religions that are being produced in the performance.

The picture also depicts the location of the photograph: Foz do Iguaçú, which is the city where the event they are dressed for took place. Instagram's geolocalization feature enables the construction of territories in digital time-spaces, showing how Djankaw has been transiting through different time-spaces along the spectrum between the countryside and big cities. Such translocal movements are part of an affective process of producing territories online, which partly dislocates Djankaw's connection with a physical geographical spot and reinserts their territorialization process in a cartographic regime that is digitally specified. The use of digital resources to construe a sense of spatialization operates as a means not only of stating the geographical whereabouts of Djankaw and their community but also of creating a moment of political resistance that is intersected on the post by showing different spaces where they get access to transit. Such semiotic resources operate by reaffirming Djankaw's existence on the app and asserts transience to the temporal-spatial dimensions of living, traveling, appearing, and belonging. The fact that a quilombola individual like Djankaw can travel to and from another city operates in a process of decomposing their territory in unexpected ways to define it as fluid as themself and their people on that platform.

\section{CONCLUSION}

By analyzing how Djankaw's posts are presented on Instagram, we understand that there are several instances of resistance on the platform. Firstly, the fact that the quilombo is being networked on the Web; this territory is thus (re)defined by the technological affordances of the Web 2.0 (O'REILLY 2007) that help broadcast this territory to a larger audience. Secondly, multiple territories are being reinserted in a cartographic regime that is digitally specified whereas it marks and delimitates time-spaces, simultaneously showing how minority groups are able to have access and to produce translocal movements between rural and urban areas. We argue that Djankaw's posts question hegemonic understandings of what it means to be a quilombola subject in contemporary Brazilian society and reaffirm their presence in different time-spaces.

Finally, the quilombo is being depicted as a harmonious place surrounded by native vegetation. However, the semiotic resources analyzed indicate that there are inner disputes and ethnic conflicts in the territory. Such articulation assembles a great array of processes: defining and resisting the specified territory and claiming 
for a multiplicity of knowledges that have not been legitimated by the existing regimes of power. In this sense, resistance is being produced in a multisemiotic array of practices that affects Djankaw's body, photographs, texts, and the digital technology itself as a "space for appearance" (BUTLER, 2018, p. 26). Their performances as a black, queer, quilombola, and religious subject both produce a political stance about the race, ethnicity, and ancestry of their people and uproots political interpretations of a quilombola body in terms of origin, gender, sexuality, and religion. These issues intersect (CRENSHAW, 1994) in the intense, multiple, and productive movements with the performative power of claiming for spaces where their political actions take place.

\section{REFERENCES}

BONFANTE, Gleiton. (2016). Erótica dos signos em aplicativos de pegação: processos multissemióticos em performances íntimo-espetaculares de si. Rio de Janeiro: Editora Multifoco.

BRAZIL. (2003) Decreto-lei n. 4. 887, de 20 de novembro de 2003. Regulamenta o procedimento para identificação, reconhecimento, delimitação, demarcação e titulação das terras ocupadas por remanescentes das comunidades dos quilombos de que trata o art. 68 do Ato das Disposições Constitucionais Transitórias, Brasília, DF.

BRAZIL. (1988) Constituição. Artigo 68 do ADCT - Direito à Propriedade das terras das comunidades remanescentes de quilombo.

BUTLER, Judith. (2018). Corpos em aliança e a política das ruas: notas para uma teoria performativa de assembleia. Rio de Janeiro: Civilização Brasileira.

CAMARGO, Mabia. (2019) "Acuenda esse bajubá: indexicalidades e interseccionalidades nas performances narrativas de uma travesti quilombola." Doctoral dissertation. Universidade Federal do Rio de Janeiro.

CARVALHO, Roberta; LIMA, Gustavo da Costa. (2013). Comunidades Quilombolas, Territorialidade e a Legislação no Brasil: uma análise histórica. Revista de Ciências Sociais, no. 39, 329-346.

COUPLAND, Nikolas. (2007). Style: language variation and identity. Cambridge University Press. 
CRENSHAW, Kimberlé. (1994) Mapping the Margins: Intersectionality, Identity Politics, and Violence Against Women of Color. New York: Routledge.

CRUZ, Marcelus, et al. (2006). "Quilombos: referência de resistência à dominação e luta pela terra no Paraná". In: História e cultura afro-brasileira e africana: educando para as relações étnico-raciais. Cadernos Temático. Curitiba: Secretaria de Estado do Paraná.

DELEUZE, Gilles. (2002) Espinosa: Filosofia prática. São Paulo: Escuta.

FABRÍCIO, Branca Falabella. (2015) Policing the borderland in a digital lusophone territory. In: MOITA LOPES, L. P. Global Portuguese: Linguistic ideologies in late modernity. New York: Routledge, 2015.

FABRÍCIO, Branca Falabella. (2020) Viagens textuais em tempo de crise. Contxt. < Available at http://contxt.letras.ufrj.br/blog/item/22-viagens-textuais.html >. Last access on September 14, 2020.

GOMES, Flávio dos Santos. (2015). Mocambos e quilombos: uma bistória do campesinato negro no Brasil. São Paulo: Claro Enigma.

GOMES, Nilma Lino. (2019). A compreensão da tensão regulação/emancipação do corpo e da corporeidade negra na reinvenção da resistência democrática. Revista Perseu, n. 17, ano 12.

HARTUNG, Mirian. (2013). "Ser E não ser", eis a questão: relatórios antropológicos, categorias nativas e Antropologia. Revista de Antropologia, USP: São Paulo, v. 56, n. 2,2013.

HARTUNG, Mirian. (2004). O sangue e o espírito dos antepassados: escravidão, berança e expropriação no grupo negro Invernada Paiol de Telha. Florianópolis: NUER/UFSC.

FOUCAULT, Michel. (1978). History of sexuality. Volume 1: An introduction. New York Pantheon Books.

O’RILLEY, Tim. (2007). What Is Web 2.0: Design Patterns and Business Models for the Next Generation of Software. Communications \& Strategies, n. 65, p. 17-37.

PENNYCOOK, Alastair. (2007). Global Englishes and transcultural flows. New York: Routledge.

POULSEN, Søren Vigild; KVÅLE, Gunhild; LEEUWEN, Theo van. (2018). Special Issue: Social media as semiotic technology. Routledge: Social Semiotics, vol. 28, n. 5, p. 593-600. 
RASSI, Natalie. (2016). Empowerment, control \& the female body: is Instagram a platform for change? University of Ottawa: Canada.

REIS, João José; MAMIGONIAN, Beatriz Gallotti. (2004). "Nagô and Mina: The Yoruba Diaspora in Brazil." In: Falola, T.; Childs, M. D. The Yoruba diaspora in the Atlantic world. Bloomington: Indiana University Press, p. 77-110.

Recebido: 15/9/2020

Aceito: 30/11/2020

Publicado: 15/1/2021 